\title{
Performance of the Public Administrator between Practices of Human Resource Management and Performance of Public Organizations: Case Study Albanian Public Administration
}

\author{
Dr. Gentiana Kraja \\ Universiteti “Aleksandër Moisiu", Durrës \\ Romina Radonshiqi MSc \\ Universiteti “Aleksandër Moisiu”, Durrës
}

Doi:10.5901/mjss.2015.v6n3s6p365

\begin{abstract}
Issues related to organizational performance and individual performance are somewhat complicated, especially when attempted to dismantle their interconnection. These find it difficult sometimes stem from the fact that individual performance is a dynamic variable and often quite complicated where it is difficult to identify own individual contribution from Organization. The main purpose of this paper is to evidence the theoretical approaches related to the performance of public administrator, components and its indicators, the relationship that this variable has to practice human resource management and performance of public organizations. Another goal of this work is to reach a conceptual theoretical model which further seen practically realized in public administration, Albanian. This work was carried out from two directions: first theoretical support concerning different approaches to individual performance and its mutual relationship with management practices and overall performance, followed by practical reflection between the creation and distribution of a questionnaire addressed to public administration. At the end of the paper reached some conclusions recommending nature.
\end{abstract}

\section{Introduction}

In the past 10 years is paid attention the identification of the relationship between human resource management and performance. However, there are serious gaps between the variables that really affect the relationship between human resource management and performance (Wright, P. M., Gardner, T. Moyniham, L.M \& Allen, M. 2005). In particular, the impact of human resource management and performance, each of the models is developed by addition of structure, variables or relationship (Alcazar, F.M., Fernandez, P.M.R., \& Gardey, G. S. 2005). A serious limitation that highlights the consideration of some literature is relation between human resource management and organizational performance is considered "black box", which means it is not a clear space in which it is not easy to say what leads where (Gerhart, B. 2005). The most critical point of issues related to the debate of human resource management and performance is precisely the relation between them and the impact each other. Empirical research that investigate the relationship between human resource practices and organizational performance confirms the importance of human resources, management and influence on organizational values (Paauwe, J., \& Boselie, P. (2008). However, there are two different approaches: some authors are defined that there is a direct relation between human resource practices and organizational performance )Schuler, R. S., \& Jackson, S. E. 2005) and according to this approach, this relation is achieved between the direct relation to the human resources strategy and organizational strategy. Other authors consider an indirect relation of human resource practices and organizational performance (Edwards, P. and Wright, M. 2001). The most important part of the debate of Human Resource Management and Performance is the relationship between them (Paauwe, J., \& Boselie P. 2005). The mechanisms of human resource management -performance help to know how human resource management leads to organizational performance.

\section{Methodology}

\subsection{The basic research questions}

Which are the components of the performance of public administrator? 
Is this performance and these components mediatory mechanism of human resource management practices in performance of public organization?

How does human resource affect to performance of public organization?

Two main aspects to achieve the goals of this study are: First is defined a theoretical framework to reflect different attitudes regarding to the practices of human resource management, black box as a mechanism for the performance of public organizations. Human resource management includes 8 main practices such as recruitment, training, motivation, job security, performance evaluation, career management, talent management and compensation. Theoretical framework of "black box" is represented by the individual inputs and outputs: first relate to skills and expertise, motivation and opportunities for participation, second are attitudes at work as: satisfaction, involvement and commitment as well as job results.

The second part of study is oriented towards practical research, data analysis is made between descriptive statistical analysis then between testing hypotheses with econometric model of multiple regression and simple linear, the method of least squares (OLS). To achieve this database are collected the primary data directly from the researcher. This process is achieved between creation and delivery of a questionnaire. The drafting of the questionnaire is focused on the theoretical framework but also in the interviews conducted for this purpose with representatives of the departments of human resources management of some public organizations. The questionnaire is designed with closed questions. The questions were in the form of statements, the interviews must to hold a position from 1 - Strongly disagree 5 - totally agree. 500 questionnaires were distributed and the data were processed on the statistical program STATA version 11.

\section{The Literature Review}

There is a real relation between human resource practices and performance of public administrator and performance of public organization. Many authors have done research about the explanation or breakdown of this relationship in order to find a mechanism that makes this relationship to work. Different authors have different views. Some say that this box depends mostly on the organization, some say that despite the impact of the organization, the way of perception of the employee is the key of success. According to Boslie (2005) "Box" is personalized by employees, in this way should have boxes equal to the number of employees. However, in the scientific literature provides a number of conceptual models, which show a casual connection between human resource practices and organizational performance. The scientific literature provides a number of conceptual models, which show a casual connection between human resource practices and organizational performance. The main purpose of these models is to show a logical of human resources management and performance, which show intermediary variables and their impact. Authors who contributed to these conceptual models are: Guest (1997), Becker, Huselid, Pickus, Spratt, (1997), Purcell, Kinnie, Hutchinson, Rayton, Swart (2003) and Wright and Nishii (2006). There are several models that try to analyze triangular mechanism of performance of public administrator, management practices and performance of public organizations for example the model of Guest (1997). According to this model the theory of expectations as motivation theory provides a base to develop a coherent reasoning about the relationship between human resources management and performance. The theory proposes that individual performance depends on high motivation, skills, perception of role. These factors influence the results of conduct, influence the behavior of the individual, which translates into performance results and financial results.

Another model is the Becker et al. (1997) This model suggests that the integration of organizational strategy and human resources strategy leads to the fact that organizational strategies lead to the design of human resources system. The practice of human resources management affect employee skills, employee motivation and job design, which constantly influences the creativity of employees, productivity and discrete behavior. These variables result in operational performance, profitable or success of the organization.

Individual-performance system (Purcell et al. 2003). This system, (it is called in the original version framework), is built on two basic suppositions, 1 . The Frame advances the concept of discretionary behavior, and suggests that virtually all employees have the capacity to have a discrete behavior. 2) the critical role of line managers, they should have a discretion to apply human resource management and way against employees. The Model of Individual-performance focuses on employee skills (they can do the work, because they have the necessary skills), motivation (they will do the work, because they want to do) and opportunities to participate (work environment provides the necessary support and opportunities to speak) (Boselie, P. 2010).

Wright and Nishii model (2006). Wright and Nishii examined some of the mediating processes that can occur in human resource management and performance, the study of relationships at multiple levels of analysis. They present the model related to target practices of human resources, current human resource practices, human resources practice perception, employee responsiveness and performance. The process of perception is a very important element in this 
model because news in this models are elements of the perception of the role of employees and psychological contract. General lines of the model starts with the relationship between employees, which are based on target practices of human resources and the current human resource practices, these affect the psychological contract and all affect in the performance of organization.

\section{Details on the elements of the mechanism of the performance of public administrator and relationship with the practices of human resource management and organizational performance.}

According to different authors cited above, in different periods of time, human resources practices, involves the employees of their individual characteristics, that they may have more psychological than managerial implications.

Human resource practices include individuals and their characteri stics which serve as the source for the application of managerial practices of human resource management, which are: skills, motivation and opportunities. If managers want to impact positively on individual performance, they must affect on these three components (Boxall, P., Purcell. J., 2003 \&2011). Briefly explain each of them:

Skills - the skill show what the individual is able to do. If the individual wants more successfully perform all the tasks that includes a certain job he must have some skill and dexterity. Skills are as the product of physiological and biological factors and the process of learning. There are authors who believe that the skills are determined by genetic factors, but there are many others who believe that skills are defined by learning (Kasimati, M. 2010).

Skill can be categorized into two main groups: the intellectual skill and physical skill. The first category includes as the important element the intellect. An important concept in the intellectual skills is emotional intelligence. A famous model of definition of skills according to various categories of employees is the model Katz (Katz, R., 1955).

According to this author, the skills are divided into three main categories: conceptual, human and technical. Lower level managers need more technical skills, human skills and less conceptual skills. Middle-level managers should have somewhat more conceptual skills, human skills and less technical skill, meanwhile the Upper- level managers should have maximum conceptual skills, human skills and minimal technical skills.

Motivation includes individual decision making, intensity and time in which the individual performs the duties (Kasimati, M. 2010).

The opportunities of participation- opportunities and challenges of skills and individual work. The opportunities of perception of the role and created psychological contract between employer and employee. The relationship between employer and employee in an organization defined by formal legal contract, but while the contract is often considered more important than legal contract is the psychological contract. The important elements of psychological contract are: objectives, goodwill, negotiations. Psychological contract is related to the commitment, the level of justice and fairness as well as the level of confidence (Luthans, F., 2011).. Psychological contract, particularly in the public sector, is quite reliable not only to the organization and the public administrator but and government with expectations and opportunities that gives the public and the public administrator (Willems, I., Janvier, R., Henderickx, E., 2004).

\section{Human Resource Results (outputs)}

The human resource performance includes the performance of human resources results. Human resource results are affected not only by human practices, but also by the perception about these practices, we remember here again Hawthorne effect, the outcome of human resources can be improved only because they perceive the attention on them, in case attention that comes through human resource practices.

The ways of perception of organizational policies have a significant impact on the performance of human resources results (Vigoda, E., Drory, A., 2006). The different authors have offered different ways of the performance of human resources results in work. Guest (1997) lists the elements which express the results in work as: commitment, quality of work, absence at work, citizenship behavior etc. Vigoda (2000) lists the elements which express the results in work as: commitment, involvement, reasons for leaving, loyalty etc. Katou (2008) lists the elements which express the results in work as: skills and competence, cooperation, commitment, satisfaction, presence etc. Paauwe dhe Richardson (2001) lists the elements which express the results in work as: job satisfaction, motivation, commitment, presence, social climate, etc.

Human resource performance is expressed by the results of human resources which consist of two main components individual inputs of human resources and outputs of human resources. The human resource practices have a greater impact on organizational performance rather than on individual performance. This is particularly the case when practices are mutually reinforcing or have a high degree of adaptability interior by creating synergies (MacDuffie, J. 1995). 
Performance- this term refers to the successful completion of the formal duties of employees in their work (Vigoda, E., 2000). Employees apply the duties set out not only in the labor contract, but also in the job description and completed tasks by standards and formal requirements to achieve performance.

Satisfaction at work- this term has various definitions such as: psychological nature, managerial nature. Psychologically can say that job satisfaction is emotion and feelings that individual at work, Locke (1976) defines job satisfaction as a positive emotional state that results of evaluation of the work or the work experience. Organizational treatment of this term is defined as the difference between what the individual expects and what he/she really takes a certain job. Job satisfaction is greater if the results achieved exceed the expected results (Ceni, A. 2011).

In recent decades job satisfaction is important because it affects commitment to work, in performance and in circulation (Gordon, J., 2002). Job satisfaction is influenced by the work and its contents, wages, opportunities for promotion that offers a certain job, supervisors, relationships with colleagues, promoting teamwork, the ways of resource management to regulate working conditions. Results of job satisfaction are: increasing performance, reduction of circulation at work, reduce the number of avoidable absenteeism, increases the commitment of individuals to the organization etc (Luthans, F., 2011).

Public organizations have three strategies to increase job satisfaction: First, communication about job responsibilities combined with an effort to procedural constraints which may lead to improved levels of job satisfaction by increasing the perception of employees on the job specifications. Secondly, specific methods to support human resources development serves to increase job satisfaction, work in the public sector is routine to an employee, so in the design of work should be paid attention to the variety of tasks that it will contain and how these tasks will combine between colleagues because public administration tends towards individualization of work (Wright E. B., Davis, S. B., 2003).

Five dominant models of job satisfaction are focused on various issues as: meeting the needs, inconsistencies, the protection of values, equality and genetic components/personal predispositions. Meeting the needs is a model, which proposes that satisfaction is determined by job characteristics, which allow the individual to satisfy his needs. Theories of discrepancies determines that job satisfaction is the result of an expectation that employees have at work.

These expectations represent the difference between what the individual expects to receive from his work as: salary, promotion opportunities, and what individual actually takes at work. When expectations are higher than what the individual receives, he will be unhappy, when the individual takes from work more than what he expected, he will be happy.

The protection of values- individuals will be satisfied when work allows to fulfill their main value. This model suggests that managers need to constitute the work and the work environment in accordance with the values of employees. In the model of justice satisfaction is a function of level of perceived justice which individuals are treated at work. This model encourages managers to be more sensitive to the perception of the fairness of the employees and interact with them in order to employees feel treated equally. Genetic / individual predispositions model explains that satisfaction at work is based on personal and genetic characteristics

\section{Commitment and Job Involvement}

Commitment to the organization is defined as the desire to be represented by the organization and as the strength of an individual to be identified with involvement in a particular organization, characterized by: a strong belief in the acceptance of the objectives and values of the organization, a great desire to stay part of the organization and the desire to make considerable efforts for the organization (Vandenabeele, W., Ban, C., 2009). Commitment and satisfaction at work are not only general results, but they are closely related and affect the results of human resources such as: circulation, performance, citizenship behavior, and social welfare. So both these elements, satisfaction and dedication are correlated with public service motivation. According to perceptions of public sector workers, they are devoted to their work. Job involvement is the extent to which the individual feels related to work, invest efforts to achieve of objectives and quality of the performance of duties. Public employees working in a work environment that is characterized by the cuts, an antipublic employee rhetoric, low levels of recognition, low morale and criticism (Steinhaus, C., Perry, J., 1996). Three important groups of public sector motives are: rational motives, motives based ethical norms and motives (Perry, J. L., \& Wise, L. R., 1990). Motivation / behavior motivated- Motivation is in the three stages of the study. If we refer to theories of organizational behavior, motivation is defined as the forces that act on or within an individual (Hellriegel, D., Slocum, W. J., 2011). Intrernal motivation is the motivation that comes from inside. This motivation is not created by external or outside rewards. Internal motivation is based on the need to be responsible and self-determined (Ryan, R., Reci, E., 2000). Internal motivation can be positively influenced by the design of the work. According to many authors of motivational effect, the work should provide sufficient variation, sufficient complexity, challenge and skill (Armstrong, M., 
2009).. Hackman and Olddham (1974) emphasize the importance of dimensions of the job as: the variety of skills, content and meaning of tasks, autonomy and feedback. External motivation happens when things become individuals in order to achieve their motivation and included bonuses as incentives, salary increase, promotion or praise, punishments such as disciplinary measures or criticism. Internal motivators, who are associated with "quality of life at work", have a deeper effect than external motivators (Armstrong, M., 2009).

Civic behavior Organization / discrete behavior- Civic behavior in the organization is defined as individual behavior that is based on self-condemnation, unknown by the official system of reward, and the total promote effective and efficient functioning of the organization (Organ, D. W. 1988). Civic behavior in the organization includes work beyond the required work tasks to promote a positive working environment, avoiding unnecessary conflicts, involvement in the activities of the organization and performance of duties beyond the normal role demands. As indicators of civic behavior in the organization are identified two distinct factors: altruism and generalized compliance. Altruism is defined as assistance to colleagues, as p.sh helping a colleague to set up a heavy load. Generalized compliance is useful behavior as for example to be in time at work (Porter, L. W., Angle, H. L., Allen. R. W., 2003).

Organ (1988), who is first author explored in this new concept, proposed five categories of civil behavior in the organization. Awareness means that employees perform behavior within the role. Altruism means that they give help to others. Civic virtue suggests that employees participate responsibly in the political life of the organization. Sports nature (fairness, respect for rules and others) shows that people do not complain and have positive attitudes. Courtesy means that they treat others with respect. Researchers have relatively few studies investigating the relationship between civic behavior and performance of the organization and denied a strong bond between them (Bolino. C. M.,Turnley. W. H, Bloodgood. J. M., 2002).. There are many theoretical evidence of other authors civic behavior in the organization has a significant contribution to organizational performance and in particular to profitability (Padsakoff. P. M., MacKenzie, S. B., Paine B. J., Bachrach G. D., (2000). Altruism and compliance is a way of civic behavior, therefore teamwork is important in public organizations (Kim, S., 2005). There is a positive correlation between civic behavior in the organization and performance of the organization. Civic behavior in the organization often is equal to the discrete behavior in the organization is part of the informal elements of the relationship that employees create in organization. Psychological contract between employer and employee helps a lot in difficult moments of organization or individual (Purcell. J. 2002).

\section{The design of the study and analysis of data}

This study content a questionnaire with 20 questions, are delivered 600 questionnaires but only 500 were valid for processing of the data. The questionnaire is delivered only in public organizations because the focus of this study was public administrator. The data are based on personal perceptions that have public administrators about the practices of human resource management, job performance of public administrator and organizational performance. The budget approved by the Ministry of Finance for 2015 was the first source to selected public institutions, than the website of each institution helped to verify the list of institutions that are subordinate, and on this basis it was created a database in the form of a genuine network of connections that served as a guide for data collection. Selection of interviewers in each institution was occasionally. The distribution and collection of the questionnaire is administered by contact persons who were trained. Electronic distribution of all clarifications were made by email contact. Data collection resulted in a relatively successful process. Key elements of the model, the variables are the practices of human resource management (8 practices: recruitment, training, performance evaluation, career management, talent management, motivation, job security and compensation), practices are independent variable of this model." Black box "or liaison mechanism of practices of human resource management and organization performance is represented by the performance of public administrator. The performance of public administrator behaves as dependent variable and independent variable. The performance of Public organization is dependent variable.

\subsection{Analysis of results}

Based on the fact of belonging to the interviewers (the central public administration, local or other category) $48.2 \%$ belong to the central public administration, $34.8 \%$ belong to the local public administration and $17.0 \%$ belong to the other category. Regarding to the characteristics of interviewers, regarding to gender shows that $38.6 \%$ are male and 61.4 are female, regarding to education $77.2 \%$ have university degrees, $21.6 \%$ have master and $1.2 \%$ have scientific degree "Doctor", regarding to position of work $77.8 \%$ of them are in the position of specialist, $16.8 \%$ of them are in the position of supervisor of the sector while $5.4 \%$ are in the position of director. 
In order to answer a very important question. Is the performance of public administrator a intermediary mechanism of human resource management in performance of public organization? The first hypothesis is: practices of human resource management have no influence on the performance of public administrator and individual characteristics.

After the regression we have the following equation:

Administrator performance pubic $'=0.3946865+0.2363811^{\prime}$ recruitment $+0.0857043^{\prime}$ training $+0.4196873{ }^{\prime}$ motivation '+ 0.0547078 ' job security '+ 0.0855328 ' performance evaluation '+ 0.0109581 ' Career direction' -0.051326 'talent management' +0.0771811 'compensation'

The model is statistically significant when $p$-value $<0,01$. The coefficient of determination $R 2=0.6414$ which means that $64.14 \%$ of the dependent variables, which means individual characteristics explained by the independent variables. To achieve this number of observations was 500 , the level of importance of this model is significant, in this way we can say that the null hypothesis falls and the alternative hypothesis is confirmed, then the practices of human resource management have an impact on the performance of public administrator.

How does the performance of human resources affect in performance of public organizations?

The performance of public administrator or "black box" change to independent variable and is a function of the performance of public organization in this case null hypothesis is Ho: individual inputs and outputs have no impact on the performance of public organizations.

"Performance of the public organization" $=0.3354109-0.0763674+$ "individual inputs" +0.6248592 "individual outputs".

The model is statistically significant when $p$-value $<0,01$. The coefficient of determination $R 2=0.7447$ which means that $74.47 \%$ of dependent variables therefore organizational performance is explained by the independent variable so the inputs and outputs of individual. The number of observations was 500 level of significance of this model is significant, in this way we can say that the null hypothesis falls and the alternative hypothesis is confirmed, then the individual inputs and outputs have a significant impact on the performance of public organizations.

\begin{tabular}{lc}
\hline Public Organization Performance & OLS \\
\hline Individual inputs (AMO) & $0.3354109^{\star \star \star}$ \\
Output & $(0.0349717)$ \\
& $0.6248592^{\star \star \star}$ \\
Gender (male) & $(0.0401422)$ \\
& -0.0062085 \\
Status (married) & $(0.0300665)$ \\
& -0.0148996 \\
Middle organizations & $(0.0379269)$ \\
& $0.2070824^{\star \star \star}$ \\
Large organization & $(0.0472201)$ \\
& $0.1572585^{\star \star \star}$ \\
Age & $(0.0489234)$ \\
& 0.0019145 \\
Years in public administration & $(0.0023928)$ \\
& -0.0046593 \\
Central public administration & $(0.0023957)$ \\
Local public organization & -0.0265551 \\
& $(0.0412123)$ \\
The number of dependents & 0.0212799 \\
& $(0.0420648)$ \\
F & -0.002792 \\
$\mathrm{R}^{2}$ & $(0.0128476)$ \\
Number of observations & 129.41 \\
$\beta_{0}$ & 0.7447 \\
Note: * 10\% statistical significance; **5\% statistical significance; \\
$\star \star \star 1 \%$ statistical significance & 500 \\
\hline
\end{tabular}

\section{Conclusions}

There is theoretical and practical evidence that prove individual performance at work affects organizational performance. 
This is affected by quantitative analysis of human resource practices that come to organizational factors and individuallevel factors. In this context, different authors have contributed to summarize the perspectives and general elements.

The most successful mechanism to explain the performance of public organizations is the impact of the practice of human resource management mediated by the performance of public administrator and his individual characteristics, so if we want to influence public organization performance through practices of human resources management can influence the performance of the individual. The main concern, especially in public administration is the performance of the practice of human resources management according to the laws which operates in public organizations.

If organizations do not pay attention the performance of public administrator and his characteristics can not increase organizational performance. Practices of human resource management are successful if tend to affect in the inputs and outputs of individuals in order to achieve the highest level of influential.

\section{References}

Alcazar, F.M., Fernandez, P.M.R., \& Gardey, G. S. (2005). Researching on SHRM: An analysis of the debate over the Role played by human resources in firm success. Management Review, 16, 213 - 241

Armstrong, M., (2009). Human Resource Management in practice. by Saxon Graphics Ltd, Derby. Fq. 318.

Armstrong, M., (2009). Human Resource Management in practice. by Saxon Graphics Ltd, Derby. Fq. 318

Becker, B.E., Huselid, MA., Pickus. PS., \& Sprats, M . (1997) . HR as a source of shareholder value :

Bolino. C. M.,Turnley. W. H, Bloodgood. J. M., (2002). Citizenship Behavior and the Creation of Social Capital in Organizations. The Academy of Management Review, Vol. 27, No. 4 Fq. 509. Fq. $505-522$.

Boselie, P. (2010). High performance work practices in the health care sector: a Dutch case study. International Journal of Manpower, 31(1), 42-58.

Boxall, P., Purcell. J., (2003) \&(2011). Strategy and Human resource management. Third edition. Pargrave Ltd. Fq. 6

Ceni, A., (2011). Menaxhimi i Shpërblimit. SHBLU. Tiranë. Fq. 242

Chand, M., \& Katou A. A. (2007). The impact of human resource management on organizational performance in the Indian hotel industry. Employee Relations, 29(6), 576-594.

Edwards, P. and Wright, M. (2001): High-involvement work systems and performance outcomes: the strength of variable, contingent and context-bound relationships. International Journal of Human Resource Management. Vol. 12(4); 568-585

Gerhart, B. (2005). Human resources and business performance. Management review, 16, 174 - 185

Gordon, J., (2002). Organizational Behavior: A Diagnostic approach. (seventh edition) Fq.83

Hackman, J R and Oldham, G R (1974) Motivation through the design of work: test of a theory, Organizational Behavior and Human Performance, 16 (2), pp 250-79

Hellriegel, D., Slocum, W. J., (2011). Organizational Behavior. Thirteenth edition. South-Western, Cengage Learning Itd. Fq. 158.

Kasimati, M. (2010). Sjellje organizative. Tiranë. Fq. 167.

Kasimati, M. (2010). Sjellje organizative. Tiranë. Fq. 35.

Katz, R., (1955). Skills of an effective Administrator. Harvard Business review. Fq. 37. Fq 33-42.

Katz, R., (1974). Retrospective Commentary. Harvard Business Review. Fq. 101. Fq 101 -102.

Kim, S., (2005). Individual level factors and organizational performance in government organizations. Journal of Public administration Research and Theory Vol. 15 No. 2. Fq. 249. Fq. 245-261.

Locke, E. (1976). The nature and causes of job satisfaction. In M. D. Dunnette (Ed.). Handbook of industrial and organizational psychology Chicago: Rand McNally. Fq. 1300. Fq (1297-1349).

Luthans, F., (2011). Organizational Behavior: An evidence based approach, 13-th edition. McGrawHill Irwin. Fq. 189,325,423.

Luthans, F., (2011). Organizational Behavior: An evidence based approach, 13-th edition. McGrawHill Irwin. Fq. 141.

MacDuffie, J. (1995). Human Resource Bundles. Industrial and Labor Relation Review 48 (2). Fq. 200. Fq 197 - 221

Organ, D. W. (1988). Organizational citizenship behavior. The good soldier syndrome. Lexington, MA: Lexington BOOKS. Fq. 4.

Organ, D. W. (1988). Organizational citizenship behavior. The good soldier syndrome. Lexington, MA: Lexington BOOKS. Fq. 253.

Organ, D. W. (1997). Organizational Citizenship Behavior: it's construct clean-up time. Human Performance 10(2). Fq. 86. Fq. 85 - 97.

Paauwe, J., \& Boselie P. (2005). HRM and performance: what next? Human Resource Management Journal, 15(4), 68-83.

Paauwe, J., \& Boselie, P. (2008). HRM and performance: What next? Human Resource Management Journal, 15(4),Fq. 71. Fq. 68-83

Padsakoff. P. M., MacKenzie, S. B., Paine B. J., Bachrach G. D., (2000) Organizational Citizenship Behaviors: A Critical Review of the Theoretical and Empirical Literature and Suggestions for Future Research, Journal of Management. Vol. 26, No. 3, Fq. 534. Fq. 513-563

Performance Link: Unlocking the black box, Research report, London: CIPD, Fq. 50

Perry, J. L., \& Wise, L. R., (1990). The motivational bases of public service. Public Administration Review, 50. Fq. 368. Fq. 367 - 373

Porter, L. W., Angle, H. L., Allen. R. W., (2003) Organizational Influence Processes, second edition. M. E. Sharpe Inc. Fq. 497

Purcell J., Kinnie, N., Hutchinson, S., Rayton, B. and Swart, J. (2003) Understanding the People

Purcell. J. (2002). Sustaining the HR and performance link in difficult times. Employment research project at the university of Bath. CIPD. Fq. 2

Research and recommendations. Human Resource Management, 36, 39-47. 
Ryan, R., Reci, E., (2000). Intrinsic and Extrinsic Motivations: Classic Definitions and New Directions. Contemporary Educational Psychology 25, Fq. 57. Fq. 54-67.

Savaneviciene, A., Stankeviciute Z., (2010). The Models Exploring the "Black Box" between HRM and Organizational Performance, ISSN 1392 - 2785 Inzinerine Ekonomika-Engineering Economics, 21(4), Fq. 430.

Schuler, R. S., \& Jackson, S. E. (2005). A Quarter-Century Review of Human Resource Management in the U.S.: The Growth in Importance of the International Perspective. Management review. Vol. 16. Issue 1. Fq. 8 Fq. 1-22.

Steinhaus, C., Perry, J., (1996). Organizational Commitment: Does Sector Matter. Public Productivity \& Management Review, Vol. 19, No. 3. Fq 279.

Study Group 3: Personnel Policies. Fq. 5.

Vandenabeele, W., Ban, C., (2009). The impact of public service in an international organization: Job Satisfaction and organizational commitment in the European Commission. International Public Service Motivation Conference. Bloomington. Fq. 7.

Vigoda, E., (2000). Organizational Politics, Job Attitudes and work Outcomes Exploration and Implications for the public Sector. Journal of Vocational Behavior 57. Fq. 335. Fq. 326 - 347

Vigoda, E., Drory, A., (2006). Handbook of Organizational Politics. Edward Elgar Publishing Limited. Fq. 29

Willems, I., Janvier, R., Henderickx, E., (2004). The unique nature of psychological contract in the public sector: an exploration. Paper to be presented at the EGPA Annual Conference, Ljubljana (Slovenia ), 1-4 September 2004

Wright, P. M., \& Nishii, L. H. (2006). Strategic HRM and organizational behaviuor: integrating multiple levels of analysis. CARHS Working Paper Series, 05. Fq. 10.

Wright, P. M., Gardner, T. Moyniham, L.M \& Allen, M. (2005). The Human Resource performance relationship: Examining casual direction. Personnel Psychology, 5. 
